Review

\title{
Extracellular Matrix Influencing HGF/c-MET Signaling Pathway: Impact on Cancer Progression
}

\author{
Heydi Noriega-Guerra and Vanessa Morais Freitas * \\ Departamento de Biologia Celular e do Desenvolvimento, Instituto de Ciências Biomédicas, Universidade de \\ São Paulo, Av. Prof. Lineu Prestes 1524, Prédio I, sala 428, 05508-000, São Paulo, SP, Brazil; hnoriegag@gmail.com \\ * Correspondence: vfreitas@usp.br; Tel.: +55-011-3091-7778
}

Received: 28 September 2018; Accepted: 20 October 2018; Published: 24 October 2018

check for updates

\begin{abstract}
The extracellular matrix (ECM) is a crucial component of the tumor microenvironment involved in numerous cellular processes that contribute to cancer progression. It is acknowledged that tumor-stromal cell communication is driven by a complex and dynamic network of cytokines, growth factors and proteases. Thus, the ECM works as a reservoir for bioactive molecules that modulate tumor cell behavior. The hepatocyte growth factor (HGF) produced by tumor and stromal cells acts as a multifunctional cytokine and activates the c-MET receptor, which is expressed in different tumor cell types. The HGF/c-MET signaling pathway is associated with several cellular processes, such as proliferation, survival, motility, angiogenesis, invasion and metastasis. Moreover, c-MET activation can be promoted by several ECM components, including proteoglycans and glycoproteins that act as bridging molecules and/or signal co-receptors. In contrast, c-MET activation can be inhibited by proteoglycans, matricellular proteins and/or proteases that bind and sequester HGF away from the cell surface. Therefore, understanding the effects of ECM components on HGF and c-MET may provide opportunities for novel therapeutic strategies. Here, we give a short overview of how certain ECM components regulate the distribution and activation of HGF and c-MET.
\end{abstract}

Keywords: c-MET; HGF; extracellular matrix; tumor microenvironment; cancer progression

\section{Introduction}

Cancer progression is not only defined by the numerous characteristics acquired by tumor cells but also includes the contributions of the tumor microenvironment [1,2]. The elaborate tumor microenvironment composed by tumor and stromal cells within the extracellular matrix (ECM) promotes neoplastic transformation, protects the tumor from the immune system and supports tumor growth, invasion and metastasis [3,4]. ECM consists of numerous proteins and macromolecules, including proteoglycans (PGs) and glycosaminoglycans (GAGs), acting as a biological barrier [5]. However, since intercellular communication in the tumor microenvironment is driven by a complex and dynamic network of cytokines, chemokines, growth factors and proteolytic enzymes, the ECM works as a reservoir for these bioactive molecules that influence tumor cell behavior [6-9].

Among the many bioactive molecules released by tumor and stromal cells, hepatocyte growth factor (HGF) is a crucial cytokine linked to promoting cancer progression [10,11]. The binding of HGF to its receptor tyrosine kinase c-MET triggers the activation of multiple downstream signaling pathways, which contribute to proliferation, growth, migration, survival, angiogenesis, invasion and metastasis [12-15]. Indeed, the HGF/c-MET system plays an essential role in tumor-stromal crosstalk [16].

The ECM's role in cancer progression is still unclear. Several ECM components, particularly proteoglycans and glycoproteins, act as signal co-receptors and/or bridging molecules, promoting 
c-MET activation. The ECM also initiates signaling events through the release of its functional fragments processed by proteolytic enzymes such as matrix metalloproteinases (MMPs). On the other hand, some components of the ECM selectively bind to various growth factors and, consequently, affect the activation of signaling pathways involved in cancer evolution [17-19]. This review focuses on understanding how the ECM can influence the HGF/c-MET signaling pathway during cancer progression. We emphasize the effect of specific ECM components on regulating the distribution and activation of HGF and c-MET.

\section{Extracellular Matrix as a Reservoir for Bioactive Molecules}

The ECM represents a complex three-dimensional network composed of fibrous (collagens and elastin) and adhesive proteins (fibronectin, laminin, thrombospondin, among others) that are embedded in a hydrated ground substance of GAGs and PGs $[5,20]$. In the tumor microenvironment, ECM components are not only synthesized and secreted by stromal cells, such as cancer-associated fibroblasts (CAFs) [2,21], but also by tumor cells [22].

As is well known, the ECM function as an anchorage site, barrier or movement track, hence playing both a negative and positive role in cancer progression [23]. Furthermore, the altered ECM serves as a reservoir for bioactive molecules, such as cytokines, growth factors, proteolytic enzymes and others [6-8]. Included among the bioactive molecules released and stored in the ECM are vascular endothelial growth factor (VEGF), hepatocyte growth factor (HGF), tumor necrosis factor alpha (TNF- $\alpha$ ), interleukin 7 (IL-7), insulin-like growth factor 1 (IGF-1), transforming growth factor beta (TGF- $\beta$ ), basic fibroblast growth factors (bFGF), epidermal growth factor (EGF) and platelet-derived growth factor (PDGF) $[18,24,25]$.

All of the molecules mentioned above are expressed and released by several types of tumor cells [26-28] and stromal cells, such as CAFs, tumor-associated macrophages (TAMs) and neutrophils (TANs) $[2,9,29]$. On the other hand, tumor and stromal cells also secrete proteolytic enzymes that modify the ECM, including MMPs (e.g., MMP-2, -7, -9, -13), A disintegrin and metalloproteinase (e.g., ADAM-8, $-10,-12,-15,-17)$, and a disintegrin and metalloproteinase with thrombospondin motifs (e.g., ADAMTS-1, -8, -13) family members [29-32]. These enzymes together with cytokines and growth factors form a complex and dynamic network that controls the autocrine and paracrine communication between tumor cells and surrounding stromal cells, thus influencing the proliferation, migration, adhesion, invasion and metastasis of malignant cells [1,7-9,33-35].

\section{Structures of Hepatocyte Growth Factor (HGF) and c-Met}

Hepatocyte growth factor (HGF, a.k.a. scatter factor) is a pleiotropic cytokine initially synthesized and secreted as a biologically inactive single-chain precursor (pro-HGF) [36,37]. However, when extracellular proteases (e.g., serine proteases and MMPs) cleave the Arg494-Val495 peptide bond of pro-HGF, this biologically inactive precursor is converted into its bioactive form [38-40]. Mature HGF is a disulfide-linked heterodimer composed of an $\alpha$ - and $\beta$-chain. The $\alpha$-chain contains an $\mathrm{N}$-terminal hairpin loop and four kringle domains (K1-K4), while the $\beta$-chain consists of a serine protease-like domain [41,42]. Moreover, it is noteworthy that the $\mathrm{N}$-terminal and the kringle one (K1) domains are responsible for the high-affinity binding of HGF to its receptor c-MET [43].

The c-MET is a receptor tyrosine kinase (RTK) encoded by the c-met proto-oncogene. c-MET is produced as a single-chain precursor and processed to the mature form by post-translational modifications [39,44]. Mature c-MET consists of an extracellular $\alpha$-chain and a transmembrane $\beta$-chain linked together by a disulfide bond [45]. The extracellular portion of c-MET consists of three domains: the N-terminal Sema domain (found in semaphorin and plexin families) that encompasses the entire $\alpha$-chain and part of the $\beta$-chain; a small PSI domain (found in Plexins, Semaphorins and Integrins); and four IPT domains (found in Immunoglobulins, Plexins and Transcription factors). Intracellularly, the c-MET receptor is composed of a juxtamembrane domain containing the Y1003 residue, which is involved in the receptor's down-regulation; a tyrosine kinase catalytic domain containing the Y1234 
and Y1235 residues, which is involved in signal transduction; and a docking site for adaptor proteins containing Y1349 and Y1356 residues [42,46,47].

Physiologically, HGF and its receptor, c-MET, play an essential role in embryonic development, organ morphogenesis, wound healing and tissue repair through activation of different signaling pathways that are involved in cell proliferation, motility, survival, differentiation, scattering and morphogenesis $[15,38,39,48]$.

\section{HGF/c-MET Signaling Pathway Mediates Cancer Progression}

The c-MET receptor interacts with HGF in a paracrine, endocrine or autocrine manner [49-51]. As soon as the Sema and IPT domains recognize HGF, two c-MET subunits dimerize, leading to the autophosphorylation of Y1234 and Y1235 residues present in the tyrosine kinase catalytic domain. This activation induces subsequent autophosphorylation of Y1349 and Y1356 residues, thus providing a docking site for the recruitment of adapter molecules (e.g., GAB1, GRB2, SHC, CRK, PI3K, PLC $\gamma 1$, SHP2 and STAT3) responsible for downstream signaling. In this way, the HGF/c-MET pathway mediates Erk/MAPK, JNK, FAK, Akt/PKB and STAT3/5 activation [42,52,53]. Nonetheless, it is important to mention that the autophosphorylation of Y1003 residue located in the juxtamembrane domain leads to internalization and degradation of the c-MET receptor. Therefore, Y1003 residue negatively regulates c-MET signaling [54].

In malignant tumors, HGF is primarily expressed and released by surrounding stromal cells, including CAFs and TAMs [16,55]. However, HGF can also be produced by several tumor cell types and is detected in the renal cell [56], colorectal [57,58] and breast carcinomas [59,60], glioma [61], multiple myeloma [62] and synovial [63], osteo- and fibrosarcoma [38]. On the other hand, the c-MET receptor is overexpressed in several solid tumors, such as medulloblastoma [64], lymphoma [65], melanoma [66], glioma [67], breast [68], pancreatic [69], colorectal, ovarian and prostate carcinomas, as well as osteo- and some soft-tissue sarcomas [38].

Therefore, tumor and stromal cells communicate with each other through HGF, creating a microenvironment that contributes to cancer progression. For example, the HGF secreted by CAFs acts on tumor cells stimulating them not only to proliferate, invade and metastasize but also to produce a variety of HGF-inducers, such as bFGF, IL-1 $\beta$, TGF- $\alpha$, PDGF and prostaglandin E2 (PGE2), that act on stromal fibroblasts. Thus, the mutual interaction between tumor and stromal cells mediated by tumor-derived HGF-inducers and stroma-derived HGF, stimulates tumor cell invasion and metastasis [2,16,70-73]. Similarly, the HGF produced by adipose-derived stem cells (ASCs), together with the c-MET expressed in primary breast carcinoma cells, increases tumor cell migration, metastasis and self-renewal through PI3K-mediated GS3K inactivation and $\beta$-catenin stabilization and nuclear accumulation [74].

On the other hand, it was shown that c-MET aberrant activation can promote glioma cell survival via PI3-kinase/ Akt signaling [75], squamous cell carcinoma invasion via STAT3 signaling [76], lymphoma cell adhesion via PI3K signaling [77], head and neck squamous cell carcinoma (HNSCC) proliferation via MAPK signaling [78], gastric cancer growth via Akt and Erk signaling [79], prostate cancer EMT and invasion via Erk/MAPK signaling [80], and breast carcinoma cell motility and lung cancer invasion via FAK signaling [81,82]. Importantly, HGF-induced tumor cell motility and invasion are accompanied by an increase in cell dissociation and protease production [e.g., MMP-2 and urokinase-type plasminogen activator (uPA)] [38,47]. Moreover, HGF/c-MET axis can stimulate the metastatic spread of colorectal tumor cells via WNT signaling [83], prostate tumor cells through induction of c-Src activity [84] and HNSCC via Erk and Akt signaling [85]. It was observed that in esophageal squamous cell carcinoma (ESCC), HGF-induced angiogenesis is driven by either pro-angiogenic cytokines (e.g., VEGF and IL-8) $[86,87]$ or independently of VEGF, through Akt and Erk activation in endothelial cells [88]. Thus, the HGF/c-MET signaling pathway induces different phenotypes and enhances the aggressive nature of tumor cells during cancer progression. 


\section{Extracellular Matrix (ECM) Interferes with HGF/c-MET Signaling Pathway Activation}

The ECM plays a critical role during cancer progression. Many ECM proteins are involved in the positive regulation of HGF/c-MET signaling. For instance, several proteases like HGFA, matriptase and MMP-2 participate in the release of mature-form HGF [89,90]. Also, MMP-1, ADAM-17 and ADAMTS-1 have "sheddase" activity and are capable of releasing membrane-bound epidermal growth factor (EGF)-like growth factors, including transforming growth factor alpha (TGF- $\alpha$ ) [91-94]. Once EGFR is activated by TGF- $\alpha$ or EGF, it interacts with c-MET [95]. Such crosstalk induces ligand-free activation of c-MET signaling and leads to increased tumor cell proliferation, survival, migration, invasion, angiogenesis, and metastasis $[96,97]$.

Some ECM components such as cell surface heparan sulfate proteoglycans (HSPGs) can bind to different growth factors and function as signal co-receptors or presenters. Indeed, CD44 and syndecan- 1 can interact and recruit HGF on the cell membrane, thereby facilitating the presentation of this ligand to c-MET [17,98-100]. CD44 also interacts with c-MET and improves tumor cell migration, invasion and metastasis [47]. Moreover, $\alpha 5 \beta 1$ and $\alpha 6 \beta 4$ integrins directly bind to c-MET and enhance its signaling. In addition, glycoproteins including laminin and fibronectin, have the ability to promote the association between c-MET and integrin $\alpha 5 \beta 1$ or $\alpha 6 \beta 4$, leading not only to ligand-free activation of c-MET but also to amplification of signaling by both receptors [101-103]. It was shown that c-MET displaces $\alpha 5$ integrin from $\beta 1$ integrin, forming a powerful structural c-Met/ $\beta 1$ complex that exhibits a greater affinity for fibronectin during the invasive and metastatic process [104].

On the other hand, some proteoglycans can interact with a large number of macromolecules (e.g., growth factors and water molecules) [105]. In general, proteoglycans consist of one or more sulfated GAG chains covalently attached to a core protein [106,107]. All GAGs (except hyaluronic acid) contain sulfate groups that render the proteoglycans negatively charged. In this way, the proteoglycan through its sulfated GAGs chains can attract positively charged growth factors $[105,108]$. It was shown that HGF binds with high affinity to heparin, specifically with $\mathrm{N}$-sulfate, 2-O-sulfate, and 6-O-sulfate groups $[109,110]$. Also, heparin has the ability to displace HGF from the HSPGs, suggesting that cell surface HSPGs present low-affinity binding sites to HGF. Specifically, the minimal heparin/heparan sulfate size for binding to HGF is an octasaccharide [111,112].

Cell-surface HSPGs act as signal co-receptors or presenters for c-MET, thus playing an important role in normal biological functions. The proteoglycans not only regulate the delivery of HGF to the target cells but also control the activity of HGF [112]. The heparin on the ECM acts as a reservoir and impairs the interaction of HGF with c-MET, leading to reduced mitogenic and motogenic responses of cells to HGF [111,113-115]. However, recent studies show that heparin can induce c-MET activation in the absence of HGF. Indeed, heparin promotes tumor-cell motility and invasion through activation of c-MET signaling pathway [116-118].

Another ECM component that is capable of sequestering HGF is the thrombospondin-1 (TSP-1), a matricellular protein involved in angiogenesis, inflammation and cancer [119]. TSP-1 binds to HGF likely through its heparin-binding domains and mobilizes HGF away from the cell surface HSPGs, thus preventing c-MET activation [120,121]. Recently, we have shown that HGF/c-MET signaling pathway can also be affected by ADAMTS-1 through a mechanism speculated to involve degradation of HGF by ADAMTS-1 or its sequestration by ADAMTS-1 TSP-1 motifs [122]. However, growth factors attached to ECM components can be released by MMPs and ADAMTSs and thus activate different signaling pathways involved in cancer progression [94].

\section{Strategies to Target HGF/cMET-ECM Interactions}

An understanding of the effects of ECM components on HGF and c-MET pathway has provided ideas to therapeutic strategies. Initially, heparin sulfate-binding peptides were designed to block interactions with its ligands, hence disturbing involved signaling pathways [123,124]. Inhibiting heparan sulfate proteoglycan synthesis or altering heparin posttranslational modifications were also considered. The sulfatase HSulf-1 is responsible for modulating heparin-binding 
growth factors, including HGF. It is involved in the sulfation of specific sites of heparan sulfate glycosaminoglycans (HSGAGs), which is critical for HGF/HS interaction. Also, HSulf- 1 was described as a negative regulator of HGF interaction with c-MET [125]. Another idea is based on the fact that HGF basic residues comprise the primary heparan sulfate (HS) binding sites. The substitution of residues on HGF sequence transformes it into a selective competitive antagonist, with the ability to block the c-MET pathway [126]. Concerning HGF/c-MET specific drugs, two major classes are described: the small molecules tyrosine kinase inhibitors (TKIs), whose mechanism of action is mainly intracellular and the human monoclonal antibodies that recognize extracellular components. A comprehensive review of these drugs was performed by De Silva et al. (2017) [127]. Monoclonal antibodies targeting HGF/c-MET pathways have been evaluated in clinical trials and are able to recognize the HGF or the c-MET extracellular domains, ultimately disturbing HGF/c-MET interaction and signaling. It has been described that the tumor-associated extracellular matrix (TAECM) masks epitopes and becomes an impediment for monoclonal antibody therapy, since accumulation of hyaluronan (HA) hampers tumor infiltration by natural killer (NK) cells and consequent tumor cell-mediated cytolysis. In addition, the use of PH20 hyaluronidase depletes tumoral HA and results in an increase of tumor cell death in the presence of trastuzumab [128]. In this way, hyaluronidase could likely be used in combination with monoclonal antibodies that target HGF/c-MET components to increase success in disturbing this signaling pathway.

\section{Conclusions}

The ECM works as a reservoir for bioactive molecules, including cytokines, growth factors and proteases that modulate tumor cell behavior. HGF produced by tumor and stromal cells acts as a multifunctional cytokine that plays an important role in cancer progression by promoting proliferation, survival, motility, angiogenesis, invasion and metastasis. However, this signaling pathway can be influenced directly or indirectly by ECM. Figure 1 summarizes the roles of several ECM components in the regulation of c-MET signaling. Among these, proteases play an essential role not only in HGF activation but also in the shedding of HB-EGF and TGF- $\alpha$, which induce the ligand-free activation of c-MET through its interaction with the activated EGFR. In addition, proteoglycans and glycoproteins can act as signal co-receptors or bridging molecules and activate c-MET. However, this activation can be disturbed by some ECM components, including matricellular proteins, proteoglycans and proteases, which bind and sequester HGF away from c-MET. Consequently, ECM components that interact with HGF and c-MET can regulate the distribution and activation of these two molecules, leading to either progression or inhibition of tumorigenesis. 


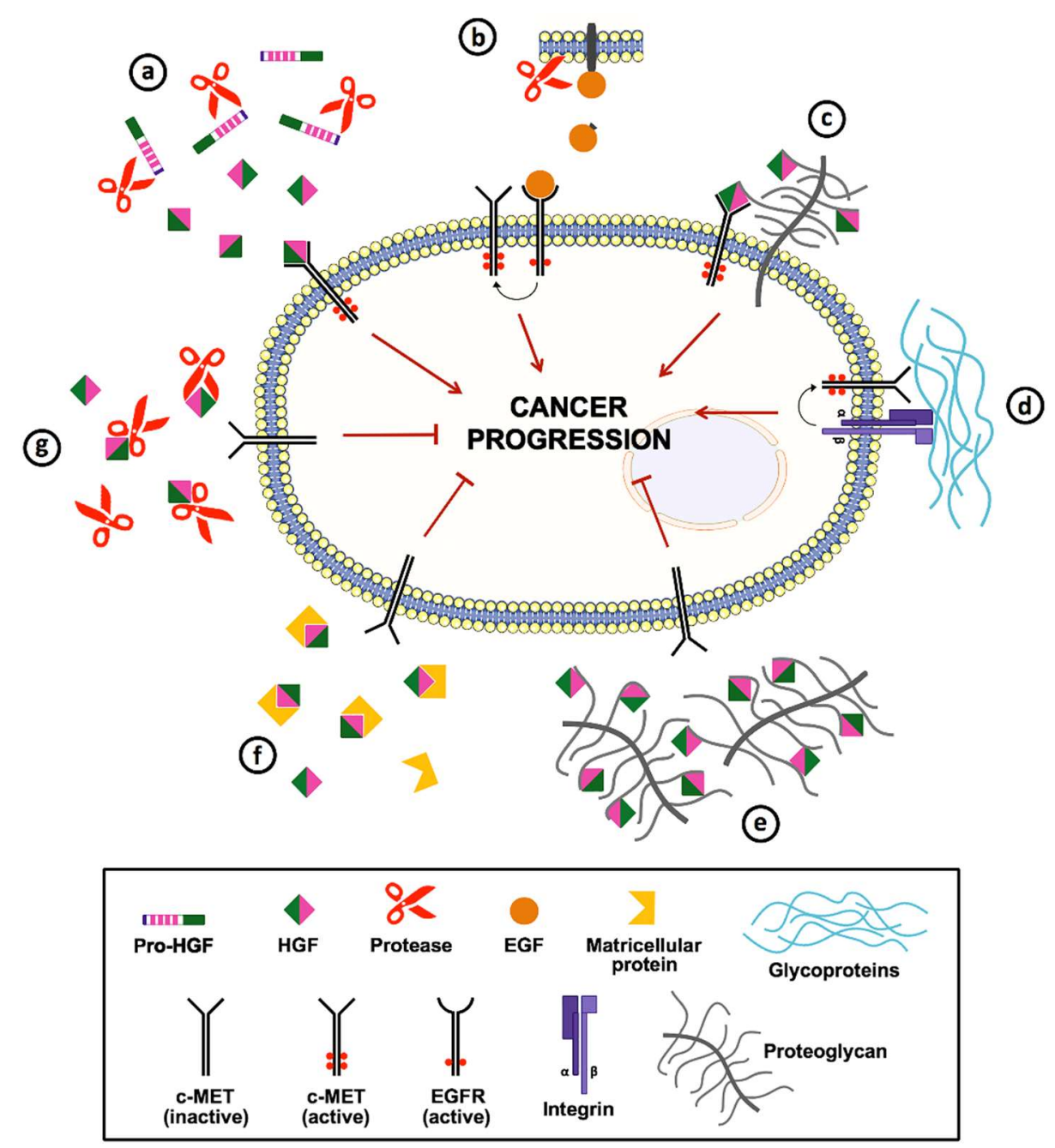

Figure 1. Schematic representation of the extracellular matrix (ECM) components implicated in the regulation of c-MET signaling. (a) Extracellular proteases (e.g., HGFA, matriptase and MMP-2) are able to cleave and convert pro-hepatocyte growth factor (HGF) (single-chain inactive precursor) into its biologically active form. (b) Besides, some proteases (e.g., MMP-1, ADAM-17 and ADAMTS-1) mediate the shedding of EGFR ligands from the cell membrane; the activated EGFR can interact with c-MET (crosstalk), resulting in the latter's ligand-free activation. (c) Cell surface heparan sulfate proteoglycans (e.g., CD44 and syndecan-1) bind to HGF and act as co-receptors and presenters for c-MET. (d) Glycoproteins (e.g., laminin and fibronectin) promote the association of integrins with c-MET, leading not only to ligand-free activation of c-MET but also to amplification of signaling by both receptors. (e) In contrast, some proteoglycans (e.g., heparin) can directly bind to HGF and prevent its interaction with c-MET. (f) Matricellular proteins (e.g., TSP-1) are another ECM components capable of sequestering HGF. (g) Also, specific proteases (e.g., ADAMTS-1) can sequester or degrade HGF, preventing the activation of HGF/c-MET signaling pathway.

Funding: This study was supported by The State of São Paulo Research Foundation (FAPESP grants 2018/05566-6,). We also acknowledge Iuri Cordeiro Valadão for critically reading the manuscript.

Conflicts of Interest: The authors declare no conflict of interest. 


\section{Abbreviations}

$\begin{array}{ll}\text { ADAM } & \text { A disintegrin and metalloproteinase } \\ \text { ADAMTS } & \text { A disintegrin and metalloproteinase with thrombospondin motifs } \\ \text { ADSCs } & \text { Adipose-derived stem cells } \\ \text { bFGF } & \text { Basic fibroblast growth factors } \\ \text { CAFs } & \text { Cancer-associated fibroblasts } \\ \text { ECM } & \text { Extracellular matrix } \\ \text { EGF } & \text { Epidermal growth factor } \\ \text { EGFR } & \text { Epidermal growth factor receptor } \\ \text { EMT } & \text { Epithelial mesenchymal transition } \\ \text { ESCC } & \text { Esophageal squamous cell carcinoma } \\ \text { GAGs } & \text { Glycosaminoglycans } \\ \text { HB-EGF } & \text { Heparin-binding epidermal growth factor } \\ \text { HGF } & \text { Hepatocyte growth factor } \\ \text { HS } & \text { Heparan sulfate } \\ \text { HNSCC } & \text { Head and neck squamous cell carcinoma } \\ \text { HSPGs } & \text { Heparan sulfate proteoglycans } \\ \text { IGF-1 } & \text { Insulin-like growth factor 1 } \\ \text { IL } & \text { interleukin } \\ \text { MMPs } & \text { Matrix metalloproteases } \\ \text { NK } & \text { Natural killer } \\ \text { PDGF } & \text { Platelet-derived growth factor } \\ \text { PGs } & \text { Proteoglycans } \\ \text { PG2E } & \text { Prostaglandin E2 } \\ \text { RTK } & \text { Receptor tyrosine kinase } \\ \text { TAMs } & \text { Tumor-associated macrophages } \\ \text { TANs } & \text { Tumor-associated neutrophils } \\ \text { TGF- } \alpha & \text { Transforming growth factor alpha } \\ \text { TGF- } \beta & \text { Transforming growth factor beta } \\ \text { TKIs } & \text { Tyrosine kinase inhibitors } \\ \text { TNF- } \alpha & \text { Tumor necrosis factor alpha } \\ \text { TSP } & \text { Thrombospondin } \\ \text { TAECM } & \text { Tumor-associated extracellular matrix } \\ \text { uPA } & \text { Urokinase-type plasminogen activator } \\ \text { VEGF } & \text { Vascular endothelial growth factor } \\ & \end{array}$

\section{References}

1. Hanahan, D.; Weinberg, R.A. Hallmarks of cancer: The next generation. Cell 2011, 144, 646-674. [CrossRef] [PubMed]

2. Hanahan, D.; Coussens, L.M. Accessories to the crime: Functions of cells recruited to the tumor microenvironment. Cancer Cell 2012, 21, 309-322. [CrossRef] [PubMed]

3. Gkretsi, V.; Stylianou, A.; Papageorgis, P.; Polydorou, C.; Stylianopoulos, T. Remodeling Components of the Tumor Microenvironment to Enhance Cancer Therapy. Front Oncol. 2015, 5, 214. [CrossRef] [PubMed]

4. Swartz, M.A.; Iida, N.; Roberts, E.W.; Sangaletti, S.; Wong, M.H.; Yull, F.E.; Coussens, L.M.; DeClerck, Y.A. Tumor microenvironment complexity: Emerging roles in cancer therapy. Cancer Res. 2012, 72, 2473-2480. [CrossRef] [PubMed]

5. Brasileiro, G.F. Bogliolo Patologia Geral, 3rd ed.; Guanabara Koogan: Rio de Janeiro, RJ, Brazil, 2004; ISBN 85-2770-892-2.

6. Yue, B. Biology of the extracellular matrix: An overview. J. Glaucoma 2014, 23, S20-S23. [CrossRef] [PubMed]

7. DeClerck, Y.A.; Mercurio, A.M.; Stack, M.S.; Chapman, H.A.; Zutter, M.M.; Muschel, R.J.; Raz, A.; Matrisian, L.M.; Sloane, B.F.; Noel, A.; et al. Proteases, extracellular matrix, and cancer: A workshop of the path B study section. Am. J. Pathol. 2004, 164, 1131-1139. [CrossRef] 
8. Bornstein, P.; Sage, E.H. Matricellular proteins: Extracellular modulators of cell function. Curr. Opin. Cell Biol. 2002, 14, 608-616. [CrossRef]

9. Mbeunkui, F.; Johann, D.J. Cancer and the tumor microenvironment: A review of an essential relationship. Cancer Chemother. Pharmacol. 2009, 63, 571-582. [CrossRef] [PubMed]

10. Spina, A.; De Pasquale, V.; Cerulo, G.; Cocchiaro, P.; Della Morte, R.; Avallone, L.; Pavone, L.M. HGF/c-MET Axis in Tumor Microenvironment and Metastasis Formation. Biomedicines 2015, 3, 71-88. [CrossRef] [PubMed]

11. Sanders, A.J.; Ye, L.; Li, J.; Mason, M.D.; Jiang, W.G. Tumour angiogenesis and repulsive guidance molecule b: A role in HGF- and BMP-7-mediated angiogenesis. Int. J. Oncol. 2014, 45, 1304-1312. [CrossRef] [PubMed]

12. De Herdt, M.J.; Baatenburg de Jong, R.J. HGF and c-MET as potential orchestrators of invasive growth in head and neck squamous cell carcinoma. Front. Biosci. 2008, 13, 2516-2526. [CrossRef] [PubMed]

13. Jiang, W.; Hiscox, S.; Matsumoto, K.; Nakamura, T. Hepatocyte growth factor/scatter factor, its molecular, cellular and clinical implications in cancer. Crit. Rev. Oncol. Hematol. 1999, 29, 209-248. [CrossRef]

14. Sugawara, J.; Fukaya, T.; Murakami, T.; Yoshida, H.; Yajima, A. Hepatocyte growth factor stimulated proliferation, migration, and lumen formation of human endometrial epithelial cells in vitro. Biol. Reprod. 1997, 57, 936-942. [CrossRef] [PubMed]

15. Trusolino, L.; Comoglio, P.M. Scatter-factor and semaphorin receptors: Cell signalling for invasive growth. Nat. Rev. Cancer 2002, 2, 289-300. [CrossRef] [PubMed]

16. Matsumoto, K.; Nakamura, T. Hepatocyte growth factor and the Met system as a mediator of tumor-stromal interactions. Int. J. Cancer 2006, 119, 477-483. [CrossRef] [PubMed]

17. Lu, P.; Takai, K.; Weaver, V.M.; Werb, Z. Extracellular matrix degradation and remodeling in development and disease. Cold Spring Harb. Perspect. Biol. 2011, 3. [CrossRef] [PubMed]

18. Hynes, R.O. The extracellular matrix: Not just pretty fibrils. Science 2009, 326, 1216-1219. [CrossRef] [PubMed]

19. Norton, W.H.; Ledin, J.; Grandel, H.; Neumann, C.J. HSPG synthesis by zebrafish Ext2 and Extl3 is required for Fgf10 signalling during limb development. Development 2005, 132, 4963-4973. [CrossRef] [PubMed]

20. Mecham, R.P. Overview of extracellular matrix. Curr. Protoc. Cell Biol. 2001. Chapter 10, Unit 10.11. [CrossRef]

21. Fu, Z.; Song, P.; Li, D.; Yi, C.; Chen, H.; Ruan, S.; Shi, Z.; Xu, W.; Fu, X.; Zheng, S. Cancer-associated fibroblasts from invasive breast cancer have an attenuated capacity to secrete collagens. Int. J. Oncol. 2014, 45, 1479-1488. [CrossRef] [PubMed]

22. Naba, A.; Clauser, K.R.; Lamar, J.M.; Carr, S.A.; Hynes, R.O. Extracellular matrix signatures of human mammary carcinoma identify novel metastasis promoters. Elife 2014, 3, e01308. [CrossRef] [PubMed]

23. Lu, P.; Weaver, V.M.; Werb, Z. The extracellular matrix: A dynamic niche in cancer progression. J. Cell Biol 2012, 196, 395-406. [CrossRef] [PubMed]

24. Zhang, X.; Nie, D.; Chakrabarty, S. Growth factors in tumor microenvironment. Front. Biosci. 2010, 15, 151-165. [CrossRef]

25. Somasundaram, R.; Ruehl, M.; Tiling, N.; Ackermann, R.; Schmid, M.; Riecken, E.O.; Schuppan, D. Collagens serve as an extracellular store of bioactive interleukin 2. J. Biol. Chem. 2000, 275, 38170-38175. [CrossRef] [PubMed]

26. Witsch, E.; Sela, M.; Yarden, Y. Roles for growth factors in cancer progression. Physiology (Bethesda) 2010, 25, 85-101. [CrossRef] [PubMed]

27. Dunlop, R.J.; Campbell, C.W. Cytokines and advanced cancer. J. Pain Symptom Manage. 2000, 20, $214-232$. [CrossRef]

28. Edwardson, D.W.; Boudreau, J.; Mapletoft, J.; Lanner, C.; Kovala, A.T.; Parissenti, A.M. Inflammatory cytokine production in tumor cells upon chemotherapy drug exposure or upon selection for drug resistance. PLoS ONE 2017, 12, e0183662. [CrossRef] [PubMed]

29. Sainio, A.; Järveläinen, H. Extracellular matrix macromolecules: Potential tools and targets in cancer gene therapy. Mol. Cell. Ther. 2014, 2, 14. [CrossRef] [PubMed]

30. Vong, S.; Kalluri, R. The role of stromal myofibroblast and extracellular matrix in tumor angiogenesis. Genes Cancer 2011, 2, 1139-1145. [CrossRef] [PubMed]

31. Mueller, M.M.; Fusenig, N.E. Friends or foes - bipolar effects of the tumour stroma in cancer. Nat. Rev. Cancer 2004, 4, 839-849. [CrossRef] [PubMed] 
32. Rocks, N.; Paulissen, G.; El Hour, M.; Quesada, F.; Crahay, C.; Gueders, M.; Foidart, J.M.; Noel, A.; Cataldo, D. Emerging roles of ADAM and ADAMTS metalloproteinases in cancer. Biochimie 2008, 90, 369-379. [CrossRef] [PubMed]

33. Grivennikov, S.I.; Greten, F.R.; Karin, M. Immunity, inflammation, and cancer. Cell 2010, 140, 883-899. [CrossRef] [PubMed]

34. Gumbiner, B.M.; Yamada, K.M. Cell-to-cell contact and extracellular matrix. Curr. Opin. Cell Biol. 1995, 7, 615-618. [CrossRef]

35. Stamenkovic, I. Matrix metalloproteinases in tumor invasion and metastasis. Semin. Cancer Biol. 2000, 10, 415-433. [CrossRef] [PubMed]

36. Miyazawa, K.; Shimomura, T.; Naka, D.; Kitamura, N. Proteolytic activation of hepatocyte growth factor in response to tissue injury. J. Biol. Chem. 1994, 269, 8966-8970. [PubMed]

37. Miyazawa, K.; Shimomura, T.; Kitamura, N. Activation of hepatocyte growth factor in the injured tissues is mediated by hepatocyte growth factor activator. J. Biol. Chem. 1996, 271, 3615-3618. [CrossRef] [PubMed]

38. Birchmeier, C.; Birchmeier, W.; Gherardi, E.; Vande Woude, G.F. Met, metastasis, motility and more. Nat. Rev. Mol. Cell Biol. 2003, 4, 915-925. [CrossRef] [PubMed]

39. Basilico, C.; Arnesano, A.; Galluzzo, M.; Comoglio, P.M.; Michieli, P. A high affinity hepatocyte growth factor-binding site in the immunoglobulin-like region of Met. J. Biol. Chem. 2008, 283, 21267-21277. [CrossRef] [PubMed]

40. González, M.N.; de Mello, W.; Butler-Browne, G.S.; Silva-Barbosa, S.D.; Mouly, V.; Savino, W.; Riederer, I. HGF potentiates extracellular matrix-driven migration of human myoblasts: Involvement of matrix metalloproteinases and MAPK/ERK pathway. Skelet. Muscle 2017, 7, 20. [CrossRef] [PubMed]

41. Donate, L.E.; Gherardi, E.; Srinivasan, N.; Sowdhamini, R.; Aparicio, S.; Blundell, T.L. Molecular evolution and domain structure of plasminogen-related growth factors (HGF/SF and HGF1/MSP). Protein Sci. 1994, 3, 2378-2394. [CrossRef] [PubMed]

42. Organ, S.L.; Tsao, M.S. An overview of the c-MET signaling pathway. Ther. Adv. Med. Oncol. 2011, 3, S7-S19. [CrossRef] [PubMed]

43. Kirchhofer, D.; Yao, X.; Peek, M.; Eigenbrot, C.; Lipari, M.T.; Billeci, K.L.; Maun, H.R.; Moran, P.; Santell, L.; Wiesmann, C.; et al. Structural and functional basis of the serine protease-like hepatocyte growth factor beta-chain in Met binding and signaling. J. Biol. Chem. 2004, 279, 39915-39924. [CrossRef] [PubMed]

44. Kim, K.H.; Kim, H. Progress of antibody-based inhibitors of the HGF-cMET axis in cancer therapy. Exp. Mol. Med. 2017, 49, e307. [CrossRef] [PubMed]

45. Cooper, C.S. The met oncogene: From detection by transfection to transmembrane receptor for hepatocyte growth factor. Oncogene 1992, 7, 3-7. [PubMed]

46. Demkova, L.; Kucerova, L. Role of the HGF/c-MET tyrosine kinase inhibitors in metastasic melanoma. Mol. Cancer 2018, 17, 26. [CrossRef] [PubMed]

47. Jeon, H.M.; Lee, J. MET: Roles in epithelial-mesenchymal transition and cancer stemness. Ann. Transl. Med. 2017, 5, 5. [CrossRef] [PubMed]

48. Corso, S.; Comoglio, P.M.; Giordano, S. Cancer therapy: Can the challenge be MET? Trends Mol. Med. 2005, 11, 284-292. [CrossRef] [PubMed]

49. Blumenschein, G.R.; Mills, G.B.; Gonzalez-Angulo, A.M. Targeting the hepatocyte growth factor-cMET axis in cancer therapy. J. Clin. Oncol. 2012, 30, 3287-3296. [CrossRef] [PubMed]

50. Peruzzi, B.; Bottaro, D.P. Targeting the c-Met signaling pathway in cancer. Clin. Cancer Res. 2006, 12, 3657-3660. [CrossRef] [PubMed]

51. Nakamura, T. Structure and function of hepatocyte growth factor. Prog. Growth Factor Res. 1991, 3, 67-85. [CrossRef]

52. Viticchiè, G.; Muller, P.A.J. c-Met and Other Cell Surface Molecules: Interaction, Activation and Functional Consequences. Biomedicines 2015, 3, 46-70. [CrossRef] [PubMed]

53. Gherardi, E.; Sandin, S.; Petoukhov, M.V.; Finch, J.; Youles, M.E.; Ofverstedt, L.G.; Miguel, R.N.; Blundell, T.L.; Vande Woude, G.F.; Skoglund, U.; et al. Structural basis of hepatocyte growth factor/scatter factor and MET signalling. Proc. Natl. Acad. Sci USA 2006, 103, 4046-4051. [CrossRef] [PubMed]

54. Peschard, P.; Fournier, T.M.; Lamorte, L.; Naujokas, M.A.; Band, H.; Langdon, W.Y.; Park, M. Mutation of the $\mathrm{c}-\mathrm{Cbl} \mathrm{TKB}$ domain binding site on the Met receptor tyrosine kinase converts it into a transforming protein. Mol. Cell 2001, 8, 995-1004. [CrossRef] 
55. Lorusso, G.; Rüegg, C. The tumor microenvironment and its contribution to tumor evolution toward metastasis. Histochem. Cell Biol. 2008, 130, 1091-1103. [CrossRef] [PubMed]

56. Porta, C.; Paglino, C.; Imarisio, I.; Ganini, C.; Sacchi, L.; Quaglini, S.; Giunta, V.; De Amici, M. Changes in circulating pro-angiogenic cytokines, other than VEGF, before progression to sunitinib therapy in advanced renal cell carcinoma patients. Oncology 2013, 84, 115-122. [CrossRef] [PubMed]

57. Fukuura, T.; Miki, C.; Inoue, T.; Matsumoto, K.; Suzuki, H. Serum hepatocyte growth factor as an index of disease status of patients with colorectal carcinoma. Br. J. Cancer 1998, 78, 454-459. [CrossRef] [PubMed]

58. Seneviratne, D.; Ma, J.; Tan, X.; Kwon, Y.K.; Muhammad, E.; Melhem, M.; DeFrances, M.C.; Zarnegar, R. Genomic instability causes HGF gene activation in colon cancer cells, promoting their resistance to necroptosis. Gastroenterology 2015, 148, 181-191.e117. [CrossRef] [PubMed]

59. Liu, S. HGF-MET as a breast cancer biomarker. Aging (Albany NY) 2015, 7, 150-151. [CrossRef] [PubMed]

60. Sheen-Chen, S.M.; Liu, Y.W.; Eng, H.L.; Chou, F.F. Serum levels of hepatocyte growth factor in patients with breast cancer. Cancer Epidemiol. Biomark. Prev. 2005, 14, 715-717. [CrossRef] [PubMed]

61. Xie, Q.; Bradley, R.; Kang, L.; Koeman, J.; Ascierto, M.L.; Worschech, A.; De Giorgi, V.; Wang, E.; Kefene, L.; $\mathrm{Su}, \mathrm{Y}$; , et al. Hepatocyte growth factor (HGF) autocrine activation predicts sensitivity to MET inhibition in glioblastoma. Proc. Natl. Acad. Sci. USA 2012, 109, 570-575. [CrossRef] [PubMed]

62. Seidel, C.; Børset, M.; Turesson, I.; Abildgaard, N.; Sundan, A.; Waage, A. Elevated serum concentrations of hepatocyte growth factor in patients with multiple myeloma. The Nordic Myeloma Study Group. Blood 1998, 91, 806-812. [PubMed]

63. Oda, Y.; Sakamoto, A.; Saito, T.; Kinukawa, N.; Iwamoto, Y.; Tsuneyoshi, M. Expression of hepatocyte growth factor (HGF)/scatter factor and its receptor c-MET correlates with poor prognosis in synovial sarcoma. Hum. Pathol. 2000, 31, 185-192. [CrossRef] [PubMed]

64. Tong, C.Y.; Hui, A.B.; Yin, X.L.; Pang, J.C.; Zhu, X.L.; Poon, W.S.; Ng, H.K. Detection of oncogene amplifications in medulloblastomas by comparative genomic hybridization and array-based comparative genomic hybridization. J. Neurosurg. 2004, 100, 187-193. [CrossRef] [PubMed]

65. Lam, B.Q.; Dai, L.; Qin, Z. The role of HGF/c-MET signaling pathway in lymphoma. J. Hematol. Oncol. 2016, 9, 135. [CrossRef] [PubMed]

66. Cao, H.H.; Cheng, C.Y.; Su, T.; Fu, X.Q.; Guo, H.; Li, T.; Tse, A.K.; Kwan, H.Y.; Yu, H.; Yu, Z.L. Quercetin inhibits HGF/c-Met signaling and HGF-stimulated melanoma cell migration and invasion. Mol. Cancer 2015, 14, 103. [CrossRef] [PubMed]

67. Koochekpour, S.; Jeffers, M.; Rulong, S.; Taylor, G.; Klineberg, E.; Hudson, E.A.; Resau, J.H.; Vande Woude, G.F. Met and hepatocyte growth factor/scatter factor expression in human gliomas. Cancer Res. 1997, 57, 5391-5398. [PubMed]

68. Lengyel, E.; Prechtel, D.; Resau, J.H.; Gauger, K.; Welk, A.; Lindemann, K.; Salanti, G.; Richter, T.; Knudsen, B.; Vande Woude, G.F.; et al. C-Met overexpression in node-positive breast cancer identifies patients with poor clinical outcome independent of Her2/neu. Int. J. Cancer 2005, 113, 678-682. [CrossRef] [PubMed]

69. Di Renzo, M.F.; Poulsom, R.; Olivero, M.; Comoglio, P.M.; Lemoine, N.R. Expression of the Met/hepatocyte growth factor receptor in human pancreatic cancer. Cancer Res. 1995, 55, 1129-1138. [PubMed]

70. Benvenuti, S.; Comoglio, P.M. The MET receptor tyrosine kinase in invasion and metastasis. J. Cell Physiol 2007, 213, 316-325. [CrossRef] [PubMed]

71. Nakamura, T.; Matsumoto, K.; Kiritoshi, A.; Tano, Y. Induction of hepatocyte growth factor in fibroblasts by tumor-derived factors affects invasive growth of tumor cells: In vitro analysis of tumor-stromal interactions. Cancer Res. 1997, 57, 3305-3313. [PubMed]

72. Matsumoto, K.; Okazaki, H.; Nakamura, T. Novel function of prostaglandins as inducers of gene expression of HGF and putative mediators of tissue regeneration. J. Biochem. 1995, 117, 458-464. [CrossRef] [PubMed]

73. Apte, R.N.; Voronov, E. Interleukin-1-a major pleiotropic cytokine in tumor-host interactions. Semin. Cancer Biol. 2002, 12, 277-290. [CrossRef]

74. Eterno, V.; Zambelli, A.; Pavesi, L.; Villani, L.; Zanini, V.; Petrolo, G.; Manera, S.; Tuscano, A.; Amato, A. Adipose-derived mesenchymal stem cells (ASCs) may favour breast cancer recurrence via HGF/c-Met signaling. Oncotarget 2014, 5, 613-633. [CrossRef] [PubMed]

75. Bowers, D.C.; Fan, S.; Walter, K.A.; Abounader, R.; Williams, J.A.; Rosen, E.M.; Laterra, J. Scatter factor/ hepatocyte growth factor protects against cytotoxic death in human glioblastoma via phosphatidylinositol 3-kinase- and AKT-dependent pathways. Cancer Res. 2000, 60, 4277-4283. [PubMed] 
76. Syed, Z.A.; Yin, W.; Hughes, K.; Gill, J.N.; Shi, R.; Clifford, J.L. HGF/c-met/Stat3 signaling during skin tumor cell invasion: Indications for a positive feedback loop. BMC Cancer 2011, 11, 180. [CrossRef] [PubMed]

77. Tjin, E.P.; Groen, R.W.; Vogelzang, I.; Derksen, P.W.; Klok, M.D.; Meijer, H.P.; van Eeden, S.; Pals, S.T.; Spaargaren, M. Functional analysis of HGF/MET signaling and aberrant HGF-activator expression in diffuse large B-cell lymphoma. Blood 2006, 107, 760-768. [CrossRef] [PubMed]

78. Tao, X.; Hill, K.S.; Gaziova, I.; Sastry, S.K.; Qui, S.; Szaniszlo, P.; Fennewald, S.; Resto, V.A.; Elferink, L.A. Silencing Met receptor tyrosine kinase signaling decreased oral tumor growth and increased survival of nude mice. Oral Oncol. 2014, 50, 104-112. [CrossRef] [PubMed]

79. Park, C.H.; Cho, S.Y.; Ha, J.D.; Jung, H.; Kim, H.R.; Lee, C.O.; Jang, I.Y.; Chae, C.H.; Lee, H.K.; Choi, S.U. Novel c-Met inhibitor suppresses the growth of c-Met-addicted gastric cancer cells. BMC Cancer 2016, 16, 35. [CrossRef] [PubMed]

80. Han, Y.; Luo, Y.; Wang, Y.; Chen, Y.; Li, M.; Jiang, Y. Hepatocyte growth factor increases the invasive potential of PC-3 human prostate cancer cells via an ERK/MAPK and Zeb-1 signaling pathway. Oncol. Lett. 2016, 11, 753-759. [CrossRef] [PubMed]

81. Beviglia, L.; Kramer, R.H. HGF induces FAK activation and integrin-mediated adhesion in MTLn3 breast carcinoma cells. Int. J. Cancer 1999, 83, 640-649. [CrossRef]

82. Chen, S.Y.; Chen, H.C. Direct interaction of focal adhesion kinase (FAK) with Met is required for FAK to promote hepatocyte growth factor-induced cell invasion. Mol. Cell Biol. 2006, 26, 5155-5167. [CrossRef] [PubMed]

83. Vermeulen, L.; De Sousa E Melo, F.; van der Heijden, M.; Cameron, K.; de Jong, J.H.; Borovski, T.; Tuynman, J.B.; Todaro, M.; Merz, C.; Rodermond, H.; et al. Wnt activity defines colon cancer stem cells and is regulated by the microenvironment. Nat. Cell Biol. 2010, 12, 468-476. [CrossRef] [PubMed]

84. Kim, S.J.; Johnson, M.; Koterba, K.; Herynk, M.H.; Uehara, H.; Gallick, G.E. Reduced c-Met expression by an adenovirus expressing a c-Met ribozyme inhibits tumorigenic growth and lymph node metastases of PC3-LN4 prostate tumor cells in an orthotopic nude mouse model. Clin. Cancer Res. 2003, 9, 5161-5170. [PubMed]

85. Zeng, Q.; Chen, S.; You, Z.; Yang, F.; Carey, T.E.; Saims, D.; Wang, C.Y. Hepatocyte growth factor inhibits anoikis in head and neck squamous cell carcinoma cells by activation of ERK and Akt signaling independent of NFkappa B. J. Biol. Chem. 2002, 277, 25203-25208. [CrossRef] [PubMed]

86. Jiang, W.G.; Martin, T.A.; Parr, C.; Davies, G.; Matsumoto, K.; Nakamura, T. Hepatocyte growth factor, its receptor, and their potential value in cancer therapies. Crit. Rev. Oncol. Hematol. 2005, 53, 35-69. [CrossRef] [PubMed]

87. Ren, Y.; Cao, B.; Law, S.; Xie, Y.; Lee, P.Y.; Cheung, L.; Chen, Y.; Huang, X.; Chan, H.M.; Zhao, P.; et al. Hepatocyte growth factor promotes cancer cell migration and angiogenic factors expression: A prognostic marker of human esophageal squamous cell carcinomas. Clin. Cancer Res. 2005, 11, 6190-6197. [CrossRef] [PubMed]

88. Sengupta, S.; Gherardi, E.; Sellers, L.A.; Wood, J.M.; Sasisekharan, R.; Fan, T.P. Hepatocyte growth factor/scatter factor can induce angiogenesis independently of vascular endothelial growth factor. Arterioscler. Thromb. Vasc. Biol. 2003, 23, 69-75. [CrossRef] [PubMed]

89. Kawaguchi, M.; Kataoka, H. Mechanisms of hepatocyte growth factor activation in cancer tissues. Cancers (Basel) 2014, 6, 1890-1904. [CrossRef] [PubMed]

90. Kataoka, H.; Kawaguchi, M.; Fukushima, T.; Shimomura, T. Hepatocyte growth factor activator inhibitors (HAI-1 and HAI-2): Emerging key players in epithelial integrity and cancer. Pathol. Int. 2018, 68, 145-158. [CrossRef] [PubMed]

91. Xiao, L.J.; Lin, P.; Lin, F.; Liu, X.; Qin, W.; Zou, H.F.; Guo, L.; Liu, W.; Wang, S.J.; Yu, X.G. ADAM17 targets MMP-2 and MMP-9 via EGFR-MEK-ERK pathway activation to promote prostate cancer cell invasion. Int. J. Oncol. 2012, 40, 1714-1724. [CrossRef] [PubMed]

92. Lu, X.; Wang, Q.; Hu, G.; Van Poznak, C.; Fleisher, M.; Reiss, M.; Massagué, J.; Kang, Y. ADAMTS1 and MMP1 proteolytically engage EGF-like ligands in an osteolytic signaling cascade for bone metastasis. Genes Dev. 2009, 23, 1882-1894. [CrossRef] [PubMed] 
93. Dang, M.; Dubbin, K.; D’Aiello, A.; Hartmann, M.; Lodish, H.; Herrlich, A. Epidermal growth factor (EGF) ligand release by substrate-specific a disintegrin and metalloproteases (ADAMs) involves different protein kinase C (PKC) isoenzymes depending on the stimulus. J. Biol. Chem. 2011, 286, 17704-17713. [CrossRef] [PubMed]

94. Egeblad, M.; Werb, Z. New functions for the matrix metalloproteinases in cancer progression. Nat. Rev. Cancer 2002, 2, 161-174. [CrossRef] [PubMed]

95. Jo, M.; Stolz, D.B.; Esplen, J.E.; Dorko, K.; Michalopoulos, G.K.; Strom, S.C. Cross-talk between epidermal growth factor receptor and c-Met signal pathways in transformed cells. J. Biol. Chem. 2000, 275, 8806-8811. [CrossRef] [PubMed]

96. Gherardi, E.; Birchmeier, W.; Birchmeier, C.; Vande Woude, G. Targeting MET in cancer: Rationale and progress. Nat. Rev. Cancer 2012, 12, 89-103. [CrossRef] [PubMed]

97. Dulak, A.M.; Gubish, C.T.; Stabile, L.P.; Henry, C.; Siegfried, J.M. HGF-independent potentiation of EGFR action by c-Met. Oncogene 2011, 30, 3625-3635. [CrossRef] [PubMed]

98. Thayaparan, T.; Spicer, J.F.; Maher, J. The role of the HGF/Met axis in mesothelioma. Biochem. Soc. Trans. 2016, 44, 363-370. [CrossRef] [PubMed]

99. Lai, A.Z.; Abella, J.V.; Park, M. Crosstalk in Met receptor oncogenesis. Trends Cell. Biol. 2009, 19, $542-551$. [CrossRef] [PubMed]

100. Derksen, P.W.; Keehnen, R.M.; Evers, L.M.; van Oers, M.H.; Spaargaren, M.; Pals, S.T. Cell surface proteoglycan syndecan-1 mediates hepatocyte growth factor binding and promotes Met signaling in multiple myeloma. Blood 2002, 99, 1405-1410. [CrossRef] [PubMed]

101. Chung, J.; Yoon, S.O.; Lipscomb, E.A.; Mercurio, A.M. The Met receptor and alpha 6 beta 4 integrin can function independently to promote carcinoma invasion. J. Biol. Chem. 2004, 279, 32287-32293. [CrossRef] [PubMed]

102. Mitra, A.K.; Sawada, K.; Tiwari, P.; Mui, K.; Gwin, K.; Lengyel, E. Ligand-independent activation of c-Met by fibronectin and $\alpha(5) \beta(1)$-integrin regulates ovarian cancer invasion and metastasis. Oncogene 2011, 30, 1566-1576. [CrossRef] [PubMed]

103. Trusolino, L.; Bertotti, A.; Comoglio, P.M. A signaling adapter function for alpha6beta4 integrin in the control of HGF-dependent invasive growth. Cell 2001, 107, 643-654. [CrossRef]

104. Jahangiri, A.; Nguyen, A.; Chandra, A.; Sidorov, M.K.; Yagnik, G.; Rick, J.; Han, S.W.; Chen, W.; Flanigan, P.M.; Schneidman-Duhovny, D.; et al. Cross-activating c-Met/ $\beta 1$ integrin complex drives metastasis and invasive resistance in cancer. Proc. Natl. Acad. Sci. USA 2017, 114, E8685-E8694. [CrossRef] [PubMed]

105. Ruoslahti, E. Structure and biology of proteoglycans. Annu. Rev. Cell. Biol. 1988, 4, 229-255. [CrossRef] [PubMed]

106. Handley, C.J.; Samiric, T.; Ilic, M.Z. Structure, metabolism, and tissue roles of chondroitin sulfate proteoglycans. Adv. Pharmacol. 2006, 53, 219-232. [CrossRef] [PubMed]

107. Miller, T.; Goude, M.C.; McDevitt, T.C.; Temenoff, J.S. Molecular engineering of glycosaminoglycan chemistry for biomolecule delivery. Acta Biomater. 2014, 10, 1705-1719. [CrossRef] [PubMed]

108. Sarrazin, S.; Lamanna, W.C.; Esko, J.D. Heparan sulfate proteoglycans. Cold Spring Harb Perspect Biol. $2011,3$. [CrossRef] [PubMed]

109. Lyon, M.; Deakin, J.A.; Mizuno, K.; Nakamura, T.; Gallagher, J.T. Interaction of hepatocyte growth factor with heparan sulfate. Elucidation of the major heparan sulfate structural determinants. J. Biol Chem. 1994, 269, 11216-11223. [PubMed]

110. Ashikari, S.; Habuchi, H.; Kimata, K. Characterization of heparan sulfate oligosaccharides that bind to hepatocyte growth factor. J. Biol. Chem. 1995, 270, 29586-29593. [CrossRef] [PubMed]

111. Mizuno, K.; Inoue, H.; Hagiya, M.; Shimizu, S.; Nose, T.; Shimohigashi, Y.; Nakamura, T. Hairpin loop and second kringle domain are essential sites for heparin binding and biological activity of hepatocyte growth factor. J. Biol. Chem. 1994, 269, 1131-1136. [PubMed]

112. Rahmoune, H.; Rudland, P.S.; Gallagher, J.T.; Fernig, D.G. Hepatocyte growth factor/scatter factor has distinct classes of binding site in heparan sulfate from mammary cells. Biochemistry 1998, 37, 6003-6008. [CrossRef] [PubMed]

113. Rosen, E.M.; Goldberg, I.D.; Kacinski, B.M.; Buckholz, T.; Vinter, D.W. Smooth muscle releases an epithelial cell scatter factor which binds to heparin. In Vitro Cell Dev. Biol. 1989, 25, 163-173. [CrossRef] [PubMed] 
114. Rubin, J.S.; Chan, A.M.; Bottaro, D.P.; Burgess, W.H.; Taylor, W.G.; Cech, A.C.; Hirschfield, D.W.; Wong, J.; Miki, T.; Finch, P.W. A broad-spectrum human lung fibroblast-derived mitogen is a variant of hepatocyte growth factor. Proc. Natl. Acad. Sci. USA 1991, 88, 415-419. [CrossRef] [PubMed]

115. Zarnegar, R.; Michalopoulos, G. Purification and biological characterization of human hepatopoietin A, a polypeptide growth factor for hepatocytes. Cancer Res. 1989, 49, 3314-3320. [PubMed]

116. İşcan, E.; Güneş, A.; Korhan, P.; Yılmaz, Y.; Erdal, E.; Atabey, N. The regulatory role of heparin on c-Met signaling in hepatocellular carcinoma cells. J. Cell. Commun. Signal. 2017, 11, 155-166. [CrossRef] [PubMed]

117. Spek, C.A.; Versteeg, H.H.; Borensztajn, K.S. Anticoagulant therapy of cancer patients: Will patient selection increase overall survival? Thromb. Haemost. 2015, 114, 530-536. [CrossRef] [PubMed]

118. Sanford, D.; Lazo-Langner, A. The effect of low molecular weight heparin on survival in cancer patients: An updated systematic review and meta-analysis of randomized trials: Reply. J. Thromb. Haemost. 2014, 12, 1574-1575. [CrossRef] [PubMed]

119. Lopez-Dee, Z.; Pidcock, K.; Gutierrez, L.S. Thrombospondin-1: Multiple paths to inflammation. Mediators Inflamm. 2011, 2011, 296069. [CrossRef] [PubMed]

120. Margosio, B.; Marchetti, D.; Vergani, V.; Giavazzi, R.; Rusnati, M.; Presta, M.; Taraboletti, G. Thrombospondin 1 as a scavenger for matrix-associated fibroblast growth factor 2. Blood 2003, 102, 4399-4406. [CrossRef] [PubMed]

121. Margosio, B.; Rusnati, M.; Bonezzi, K.; Cordes, B.L.; Annis, D.S.; Urbinati, C.; Giavazzi, R.; Presta, M.; Ribatti, D.; Mosher, D.F.; et al. Fibroblast growth factor-2 binding to the thrombospondin-1 type III repeats, a novel antiangiogenic domain. Int. J. Biochem. Cell Biol. 2008, 40, 700-709. [CrossRef] [PubMed]

122. Noriega-Guerra, H.; Cruz, M.C.; Ribeiro, P.R.L.; Strnadel, J.; Wang, H.; Klemke, R.L.; Jaeger, R.G.; Freitas, V.M. ADAMTS-1 disrupts HGF/c-MET signaling and HGF-stimulated cellular processes in fibrosarcoma. Exp. Cell. Res. 2018, 363, 271-282. [CrossRef] [PubMed]

123. Cardin, A.D.; Weintraub, H.J. Molecular modeling of protein-glycosaminoglycan interactions. Arteriosclerosis 1989, 9, 21-32. [CrossRef] [PubMed]

124. Sanderson, R.D.; Yang, Y.; Suva, L.J.; Kelly, T. Heparan sulfate proteoglycans and heparanase-partners in osteolytic tumor growth and metastasis. Matrix Biol. 2004, 23, 341-352. [CrossRef] [PubMed]

125. Lai, J.P.; Chien, J.; Strome, S.E.; Staub, J.; Montoya, D.P.; Greene, E.L.; Smith, D.I.; Roberts, L.R.; Shridhar, V. HSulf-1 modulates HGF-mediated tumor cell invasion and signaling in head and neck squamous carcinoma. Oncogene 2004, 23, 1439-1447. [CrossRef] [PubMed]

126. Cecchi, F.; Pajalunga, D.; Fowler, C.A.; Uren, A.; Rabe, D.C.; Peruzzi, B.; Macdonald, N.J.; Blackman, D.K.; Stahl, S.J.; Byrd, R.A.; et al. Targeted disruption of heparan sulfate interaction with hepatocyte and vascular endothelial growth factors blocks normal and oncogenic signaling. Cancer Cell 2012, 22, 250-262. [CrossRef] [PubMed]

127. De Silva, D.M.; Roy, A.; Kato, T.; Cecchi, F.; Lee, Y.H.; Matsumoto, K.; Bottaro, D.P. Targeting the hepatocyte growth factor/Met pathway in cancer. Biochem. Soc. Trans. 2017, 45, 855-870. [CrossRef] [PubMed]

128. Singha, N.C.; Nekoroski, T.; Zhao, C.; Symons, R.; Jiang, P.; Frost, G.I.; Huang, Z.; Shepard, H.M. Tumor-associated hyaluronan limits efficacy of monoclonal antibody therapy. Mol. Cancer Ther. 2015, 14, 523-532. [CrossRef] [PubMed]

(c) 2018 by the authors. Licensee MDPI, Basel, Switzerland. This article is an open access article distributed under the terms and conditions of the Creative Commons Attribution (CC BY) license (http://creativecommons.org/licenses/by/4.0/). 